NBER WORKING PAPER SERIES

\title{
FOREIGN FIRMS AND EXPORT PERFORMANCE \\ IN DEVELOPING COUNTRIES: \\ LESSONS FROM THE DEBT CRISIS
}

Magnus Blomstrom

Robert E. Lipsey

Working Paper No. 3412

\author{
NATIONAL BUREAU OF ECONOMIC RESEARCH \\ 1050 Massachusetts Avenue \\ Cambridge, MA 02138 \\ August 1990
}

Blomstrom's participation in this profect was supported by the Swedish Agency for Research Cooperation with Developing Countries and the Swedish Council for Research in the Humanities and Social Science. We are grateful to Tijana Perl for comments at a session of the Western Economic Association, to Linda Molinari and Zhang Qing for programing and statistical work, and to James Hayes and Rosa Schupbach for the preparation of the manuscript. The research reported here is part of the NBER's program in International Studies. Any opinions expressed are those of the authors and not those of the National Bureau of Economic Research. 


\title{
August 1990 \\ FOREIGN FIRMS AND EXPORT PERFORMANCE \\ IN DEVELOPING COUNTRIES : \\ LESSONS FROM THE DEBT CRISIS
}

NBER Working Paper \#3412

\begin{abstract}
Th1s paper compares U.S.-owned affiliates with other firms in developing countries with respect to the shifts in sales from home to export markets in response to the debt crisis of the early 1980s. The U.S. affiliates in heavily indebted countries increased their exports and the share of their production exported more rapidly than other firms did after 1982, while affiliates in less indebted countries did neither. However, a large part of the shift in sales by affiliates in the heavily indebted countries involved sharp reductions in local sales, often larger than the growth in exports.
\end{abstract}

\author{
Magnus Blomstrom \\ Stockholm School of Economics \\ Box 6501 \\ 11383 Stockholm, SWEDEN \\ and \\ NBER \\ 269 Mercer Street, 8th floor \\ New York, N.Y. 10003
}

\author{
Robert E. Lipsey \\ Queens College and The Graduate P.O. \\ Center, CUNY \\ Flushing, N.Y. 11367 \\ and \\ NBER \\ 269 Mercer Street, 8 th floor \\ New York, N.Y. 10003
}


FOREIGN FIRMS AND EXPORT PERFORMANCE IN DEVELOPING COUNTRIES:

Magnus Blomström and Robert E. Lipsey*

\section{Introduction}

In the backwash of the debt financing of the 1970 s and the worldwide recession of the early 1980s, when many developing countries have run into serious debt-servicing difficulties, shifting production from domestic to export markets has been one means for these countries to get badly needed foreign currencies. In this paper, we examine the extent to which a number of developing countries have redirected their sales of manufactured goods to world markets and the role of multinational corporations (MNCs) in this shift. We are particularly interested in investigating whether affiliates of multinational firms are better equipped to redirect their sales than local firms in developing countries.

It is not difficult to think of reasons why multinationals should have an easier time switching markets than other firms. MNCs have internal markets already set up to supplenent external markets. This could give them opportunities to switch their sales of finished products or components from local to overseas markets. MNCs also presumably have greater access than local firms to market information, distribution channels, and international marketing skills, all which facilitate access to export markets.

\footnotetext{
*The research reported here is part of the NBER's program in International Studies. Blomstrom's participation in this project was supported by the Swedish Agency for Research Cooperation with Developing Countries and the Swedish Council for Research in the Humanities and Social Science. We are grateful to Tijana Perl for comments at a session of the Western Economic Association, to Linda Molinari and Zhang Qing for programing and statistical work, and to James Hayes and Rosa Schupbach for the preparation of the manuscript. Any opinions expressed are those of the authors and do not necessarily represent the views of the National Bureau or any of the sponsoring agencies.
} 
There are a number of possible measures of "export performance" by countries and groups of firms that one could use. One is the rate of growth of exports. Another might be the growth of exports to developed country markets, the more competitive part of world markets and the ones in which the exporters would be sure to earn convertible currency. Sti11 another would take account of the industries in which exports were originally concentrated and measure the degree to which the countries' or firms' export growth exceeded or fell short of what it would have been if it had simply kept up with the world growth of exports in each industry.

A somewhat different way of judging export performance would be to examine the proportion of output exported, or the propensity to export, assuming that one of the tasks of adjustment is that of shifting sales from domestic to export markets. An ambiguity in changes in the propensity to export is that a rise could be achieved by increasing exports from increasing production, by moving sales from local to export markets without changing production, or simply by reducing domestic sales or even reducing both export and domestic sales, but the latter more rapidly. clearly, the last would be the least desirable form of adjustment from the point of view of the host country.

The debt crisis began in 1982 when Mexico realized that it could not fulfill its international payments obligations. A number of countries followed Mexico into default, and today several countries face severe debt problems. Of the countries considered by the IMF to be "heavily indebted," and by the World Bank to be "highly indebted," we study in our analysis below six for which data on U.S. multinationals' trade are available, and compare them with a less heavily indebted group of countries for which we also have MNC 
data. We take 1977-1982 to represent the period before the debt crisis and 1982-1986 to represent the debt crisis era.

\section{The Export Performance of Countries}

The manufactured exports of the whole group of countries we are examining were increasing rapidly in nominal terms, expressed in U.S. dollars, in the five years before the debt crisis (Table 1). The countries that were not later labelled as heavily indebted raised their manufactured exports (in SUS) by over 15 per cent per annum between 1977 and 1982, while the heavily indebted countries increased their exports by a 1 ittle under 10 per cent per annum. After 1982, the rate of increase was a little under 10 per cent per year for the more indebted group and 11 per cent for the less indebted, including Taiwan.

A somewhat different picture of the two periods is given by the third and fourth columns of the table, which show the same export growth in terms of the purchasing power over U.S. manufactured exports. In these terms, the less indebted countries are seen to have enjoyed substantial real export growth in manufactures between 1977 and 1982 and then even faster growth after 1982 than before: a rise in the growth rate by almost one third. The heavily indebted countries are shown to have had little real manufactures export growth in the 1977-82 period, and in three of the six countries, real exports of manufactured goods declined. However, as a group they enjoyed rapid real export growth after 1982, equal to that of the less indebted countries, on average. Two of the three countries with negative real export growth in the earlier period had more rapid export growth in 1982-86 than any of the less indebted countries, except Taiwan. However, three of the heavily indebted countries were still at the bottom of the export growth 1 ist after 1982 . 
Table 1

Average Annual Growth Rates of Manufactured Exports (Per Cent) Twelve Developing Countries, 1977 to 1982 and 1982 to 1986

\begin{tabular}{|c|c|c|c|c|}
\hline & Nomin & 1 Values & $\begin{array}{l}\text { Purchasir } \\
\text { U.S. Manuf: }\end{array}$ & $\begin{array}{l}\text { ower over } \\
\text { red Exports }\end{array}$ \\
\hline & $977-1982$ & $1982-1986$ & $1977-1982$ & $1982-1986$ \\
\hline All Developing Countries & 11.2 & 8.6 & 2.5 & 6.6 \\
\hline Latin America & 6.8 & 7.2 & -1.4 & 5.1 \\
\hline Asia, except Middle East & 14.9 & 10.5 & 5.9 & 8.4 \\
\hline Individual Countries & & & & \\
\hline Heavily Indebted Countries & & & & \\
\hline Brazil & 11.3 & 4.4 & 2.7 & 2.4 \\
\hline Chile & 6.6 & 3.3 & -1.7 & 1.5 \\
\hline Colombia & 2.3 & 13.3 & -5.6 & 11.2 \\
\hline Mexico & 8.0 & 26.9 & -.4 & 24.5 \\
\hline Venezuela & 29.4 & 19.4 & 19.3 & 17.1 \\
\hline Five Latin American Countries & 9.6 & 10.1 & 1.0 & 8.0 \\
\hline Philippines & 10.1 & 3.6 & 1.6 & 1.7 \\
\hline SIX HEAVILY INDEBTED COUNTRIES & is 9.6 & 9.5 & 1.0 & 7.6 \\
\hline Less Indebted Countries & & & & \\
\hline Hong Kong & 12.6 & 9.5 & 3.9 & 7.6 \\
\hline India & 3.2 & 5.1 & -4.8 & 3.1 \\
\hline Malaysia & 14.2 & 4.9 & 5.2 & 2.9 \\
\hline Singapore & 22.0 & 6.8 & 12.5 & 4.9 \\
\hline South Korea & 17.4 & 12.3 & 8.3 & 10.1 \\
\hline Thailand & 16.9 & 12.3 & 7.7 & 10.1 \\
\hline FOUR LESS INDEB'TED COUNTRIES ${ }^{a}$ & 16.4 & 9.5 & 7.4 & 7.6 \\
\hline SIX LESS INDEBTED COUNTRIES & 14.8 & 9.4 & 5.9 & 7.4 \\
\hline Taiwan & 19.0 & 15.8 & 9.7 & 13.7 \\
\hline $\begin{array}{l}\text { FIVE LESS INDEBTED COUNTRIES, } \\
\text { incl. Triwan }\end{array}$ & 17.2 & 11.4 & 8.0 & 9.4 \\
\hline $\begin{array}{c}\text { SEVEN LESS INDEBTED COUNTRIES, } \\
\text { incl. Taiwan }\end{array}$ & 15.8 & 11.0 & 6.8 & 9.0 \\
\hline
\end{tabular}

$a_{\text {Hong Kong, Malaysia, Singapore, and South Korea }}$ Source: Appendix Table A. 


\section{The Export Performance of Manufacturing Affiliates of U.S. Firms}

The export performance of U.S. affiliates in the same countries and in two geographical areas during the same two periods is described in Table 2 . In the heavily indebted countries, these affiliates expanded their exports more rapidly than other firms in both periods, although the margin was somewhat reduced after 1982. In real terms, their export growth accelerated after the start of the debt crisis. However, this acceleration was entirely accounted for by affiliates in Mexico; in all the other countries of this group for which we can make the calculation, there was a deceleration of export growth after 1982. And that slowdown of growth was aiso evident for affiliates in all Latin American countries.

In the less indebted group of developing countries, the rate of export growth in reai terms by U.S. affiliates was clearly lower after 1982 than before, although there were a couple of exceptions, in Singapore and Taiwan. Although the individual country data are somewhat skimpy, the comparisons with aggregate export growth in the less indebted countries suggest that the U.S. multinationais' affiliates led the countries' export growth before 1982, but lagged after that, and that is certainly the case for developing Asian countries as a group.

An important difference between the two groups of developing countries is that while U.S. firms are the major muitinationals in Latin America, and therefore among the heavily indebted countries, but that is not the case among the other developed countries listed. In these, all Asian countries, Japanese firms play more of a role than U.S. firms. Thus, the U.S, affiliates are a good approximation of multinationals in general in Latin America, while in the Asian countries, a large part of the exports by multinationals were by 
Average Annual Growth Rates of Exports by U.S. Majority-owned Manufacturing Affiliates in Developing Countries, by Region, State of Indebtedness, and Country, 1977 to 1982 and 1982 to 1986

All Developing Countries

Latin America

Asia, except Middle East

Individual countries

Heavily Indebted Countries

$$
16 .
$$

Brazi

Colombi

Mexico

Venezuela

Three Latin American Countries

Philippines

FOUR HEAVILY INDEBTED COUNTRIES

Less Indebted Countries

Hong Kong

India

Malaysia

Singapore

South Korea

Thailand

FOUR LESS IHDEETED COUNTRIES

Tairan

FIVE LESS INDEBTED COUNTRIES, incl. Teiran
Nominal Values 1977-1982 1982-1986

Purchasing Power Over U.S. Menufactured Exports 1977-1982 1982-1986

$\begin{array}{cccc}15.3 & 7.4 & 6.3 & 5.3 \\ 14.9 & 8.4 & 5.9 & 6.4 \\ 16.1-16.7 & 5.9-6.6 & 7.1-7.6 & 4.0-4.7\end{array}$

7.1

NA

.6

7.0

NA

7.0

2.7

6.3

1.0

$15.3 \quad 13.2$

7.9

NA

31.2

16.0

15.2

NA

0.0
NA
$5.9-7.8$
12.6
7.0
NA

$-.6$

NA

21.0

7.0

6.2

NA

5.1

HA

$-4.6$

24.3

16.5

7.4

$7 \cdot 4$

5.3

9.7

10.5

1.2

8.4

15.3

8.0

6.3

\footnotetext{
Brazil, Colombia, and Mexico

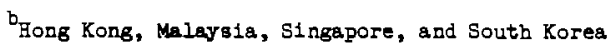

Source: Appendix Table B
} 
Japanese firms and are not included in our data.1

\section{The Export Propensities of Affiliates of U.S. MNCS}

There has been a long-term trend toward greater export orientation among the foreign affiliates of U.S. firms. It has been present in affiliates in both developed and developing countries, but the export propensity of affiliates in developing countries was, in 1977, only a little over half that of those in developed countries, and in 1982, still less than two-thirds as large (Table 3). Between 1982 and 1986, however, the export propensities of LDC affiliates leaped, rising by almost 50 per cent, to over 80 per cent of that of affiliates in developed countries. That sudden, dramatic shift was centered in the heavily indebted countries, a fact that suggests the possibility that the debt crisis may have had some role in the transformation.

U.S. affiliates in the five Astan countries not in the heavily indebted class, for which we have complete data in Table 3, have had high export propensities throughout the period since 1977 . There is little difference in export behavior between the first and last years, on average, although there are some substantial shifts in individual countries. A11, except those in India, had export propensities above 50 per cent in all three years.

Among affiliates in the heavily indebted countries, the course of events was very different. They were far less export-oriented than those in the other group in 1977 (exports 10 per cent of sales, as compared with 80 per cent). Between 1982 and 1986, however, those in almost every heavily indebted country moved strongly toward exporting, to an export propensity in 1986 more than twice that of 1977. An indication that indebtedness, rather than geographical

1Blomström, Kravis, and Lipsey (1988), Appendix Table 3. 
Table 3

Export Propensities (Exports as Per Cent of Total Sales)

of U.S. Majority 0 wned Manufacturing Affiliates in Developing Countries, by Region, State of Indebtedness, and Country 1977,1982 , and 1986

All Developed Countries

All Developing Countries

Latin America

Asia, except Middle East

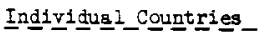

Hesvily Indebted Countries

Brazil
Chtle
Colombis
Mexico

Venezuela

Three Latin American Countrieg

Philippines

FOUR HEAVILY INDEBTHD COUNTRIDS

Less Indebted Countries

Hong Kong
India
Malaysia
Singspore
South Korea
Thailand

FOUR LEBS INDGBTED COUITRTES ${ }^{c}$

Taitran

FIVE LESS IIDERTEN COUNTRTAS incl. Taiwan

\begin{tabular}{|c|c|c|}
\hline 1977 & 1982 & 1986 \\
\hline 33.1 & 36.6 & 39.2 \\
\hline 18.1 & 22.0 & 32.5 \\
\hline 9.7 & 11.9 & 20.0 \\
\hline 57.0 & $60-60.6$ & 66.8 \\
\hline
\end{tabular}

$\begin{array}{rcc}8.9 & 12.4 & 16.9 \\ 16.1 & \text { NA } & 27.8^{\mathrm{a}}(32.1)^{\mathrm{d}} \\ 3.9 & 3.3 & 3.7^{\mathrm{a}} \\ 10.4 & 10.8 & 34.5 \\ 0.4 & \text { NA } & 2.4 \\ 9.0 & 11.3 & 21.5 \\ 25.7 & 26.5 & 39.4 \\ 10.0 & 12.1 & 22.4\end{array}$

$\begin{array}{rcc}80.5 & 77.4 & 71.8 \\ 3.6 & \text { NA } & 3.7 \\ 76.2 & 81.5 & 83.7-89.8 \\ 93.2 & 91.8 & 89.7 \\ 68.4 & 62.8 & 58.0 \\ \text { NA } & \text { NA } & 58.5 \\ 83.6 & 82.9 & 82.1-83.8 \\ 70.9 & 59.4 & 63.7 \\ 80.4 & 77.5 & 77.8-79.2\end{array}$

$a_{1985} b_{B r a z 11}$, Colombia, and Mexico

cHong Kong, Malaygia, Singapore, and South Korea d d

Source: Appendix Tables $B$ and $C$ 
location, was a determinant of this shift, is the fact that affiliates in the one heavily indebted Asian country in our list. The Philippines, shifted toward exporting as much as the Latin American affiliates did.

How was this shift in the orientation of sales carried out? It could conceivably have been done by increases in production dedicated to export markets. In fact, the increasing export propensities of U.S. manufacturing affiliates in developing countries as a group, and especially in Latin America and in heavily indebted countries, were to a large extent the result of decreasing sales, and particularly decreasing domestic sales, rather than increasing exports (see Table 4). While the exports of U.S. affiliates in Latin America increased by $\$ 1.9$ billion (or 42 per cent) between 1982 and 1986, their local sales decreased by almost \$9 billion, or 25 per cent over the same period. In developing Asia, in contrast, both exports and domestic sales grew, but export growth was much larger; the export growth did not come from dectining domestic consumption.

The comparison between the heavily indebted countries and the others is the most significant here. Presumably, as a consequence of restrictive macroeconomic policies brought about by the debt problems of these countries, the local sales of U.S. manufacturing affiliates fell by $\$ 5.7$ billion, or over 20 per cent. Exports rose by about $\$ 2.3$ billion, so that about 40 per cent of what were formerly local sales were shifted to export markets. In contrast, the less indebted countries in the list increased both local sales and exports, but exports grew more rapidly.

\section{Export Propensities of Countries}

We would like to compare affiliate behavior with that of domestic firms 
Table 4

Change in Total Sales, Local Sales, and Exports, 1982-1986, U.S. Majority-Owned Manufacturing Affiliates in Developing Countries

\begin{tabular}{|c|c|c|c|}
\hline & Sales & $\begin{array}{l}\text { Local } \\
\text { Sales }\end{array}$ & Exports \\
\hline All Developing Countries & $-5,249$ & $-8,917$ & 3,668 \\
\hline Latin America & $-7,029$ & $-8,829$ & 1,800 \\
\hline Developing Asia & 1,979 & -23 to 47 & $1,932-2,002$ \\
\hline \multicolumn{4}{|l|}{ Individual Countries } \\
\hline \multicolumn{4}{|l|}{ Heavily Indebted Countries } \\
\hline Brazil & -668 & $-1,323$ & 655 \\
\hline Chile & -4 & NA & $\mathrm{NA}$ \\
\hline Colombia & -530 & -524 & -6 \\
\hline Mexico & $-1,782$ & $-3,403$ & 1,621 \\
\hline Venezuela & $-3,105$ & NA & $\mathrm{NA}$ \\
\hline THREE LATIN AMERICAN COUNTRIES ${ }^{\mathrm{a}}$ & $-2,980$ & $-5,250$ & 2,270 \\
\hline Philippines & -415 & -468 & 53 \\
\hline FOUR HEAVILY INDEBTED COUNTRIES & $-3,395$ & $-5,718$ & 2,323 \\
\hline \multicolumn{4}{|l|}{ Less Indebted Countries } \\
\hline Hong Kong & 83 & 87 & -4 \\
\hline India & $80^{\circ}$ & NA & NA \\
\hline Malaysia & 365 & -97 to 25 & $340-462$ \\
\hline Singapore & 1,225 & 167 & 1,058 \\
\hline South Korea & 174 & 93 & 81 \\
\hline Thailand & 111 & NA & NA \\
\hline FOUR LESS INDEBTED COUNTRIES ${ }^{b}$ & 1,847 & $250-372$ & $1,475-1,597$ \\
\hline Taiwan & 578 & 146 & 432 \\
\hline $\begin{array}{l}\text { FIVE LESS INDEBTED COUNTRIES, } \\
\text { incl. Taiwan }\end{array}$ & 2,425 & $396-518$ & $1,907-2,029$ \\
\hline
\end{tabular}

$a_{\text {Brazil, Colombia, and Mexico }}$

$b_{\text {Hong Kong, Malaysia, Singapore, and South Korea }}$

Source: Appendix Tables B and C 
across regional and indebtedness groupings. However, we do not have regional production data and are limited to some comparisons between affitiates and their host countries for individual countries.

The production data we do have (gross output at producers' prices) are, for at least some of the countries, incomplete, and incomplete to a changing extent over time. The country export propensities derived using these output figures as denominators are almost certainly overstated, both because the output estimates are incomplete in coverage, often omitting small plants, and because they are in producers' prices, while exports add costs of transportation to the border and other costs incurred by intermediaries such as wholesalers.

The national export propensities for manufactures estimated from these data (Table 5) show clearly the much higher export orientation of Asian, as compared with Latin-American manufacturing industries, and the lower export orientation of the heavily indebted countries relative to the others. Most Asian countries' export propensities were increasing.

The average export propensity in heavily indebted countries, starting from a much lower level than those of the other group, rose by over 60 per cent between 1982 and 1986 . Several of the individual countries showed increases of more than 50 per cent in those four years.

Thus, while export propensities in heavily indebted countries were still relatively low in 1986, some force had apparently encouraged a shift for domestic sales to exporting.

Although the country export propensities for Latin America (Table 5) appear higher than those for U.S. affiliates (Table 3) more often than not, that comparison is inconclusive because the denominators in the country 
Table 5

Export Propensities (Exports as Per Cent of Value of Output)

in Twelve Developing Countries in Manufacturing

1977,1982 , and 1986

\begin{tabular}{|c|c|c|c|}
\hline & 1977 & 1982 & 1986 \\
\hline \multicolumn{4}{|l|}{ Heavily Indebted Countries } \\
\hline $\begin{array}{l}\text { Brazil } \\
\text { Chile } \\
\text { Colombia } \\
\text { Mexico } \\
\text { Venezuela }\end{array}$ & $\begin{array}{r}\text { NA } \\
25.3 \\
21.9 \\
4.9 \\
1.1\end{array}$ & $\begin{array}{r}\text { NA } \\
21.3 \\
13.3 \\
4.3 \\
2.1\end{array}$ & $\begin{array}{c}\text { NA } \\
24.0 \\
23.2 \\
\text { NA } \\
4.9\end{array}$ \\
\hline $\begin{aligned} \text { Latin America, } & 4 \text { Countries }_{b}^{a} \\
& 3 \text { Countries }\end{aligned}$ & $\begin{array}{r}7.6 \\
11.5\end{array}$ & $\begin{array}{l}6.1 \\
8.5\end{array}$ & $\begin{array}{l}\text { NA } \\
13.8\end{array}$ \\
\hline Philippines & 14.8 & 13.0 & 22.5 \\
\hline TOTAL 5 COUNTRIES & 8.4 & 6.9 & NA \\
\hline TOTAL 4 COUNTRIES & 12.2 & 9.5 & 15.3 \\
\hline \multicolumn{4}{|l|}{ Other Developing Countries } \\
\hline $\begin{array}{l}\text { Hong Kong } \\
\text { India } \\
\text { Malaysia } \\
\text { Singapore } \\
\text { South Korea } \\
\text { Thailand }\end{array}$ & $\begin{array}{c}\text { NA } \\
12.1 \\
\text { NA } \\
58.8 \\
29.7 \\
\text { NA }\end{array}$ & $\begin{array}{r}61.5 \\
7.0 \\
44.2 \\
68.9 \\
29.8 \\
15.2\end{array}$ & $\begin{array}{c}66.0 \\
\text { NA } \\
52.6 \\
89.7 \\
32.1 \\
\text { NA }\end{array}$ \\
\hline TOTAL 4 COUNTRIES $^{c}$ & NA. & 50.5 & 46.0 \\
\hline TOTAL 3 COUNTRIES ${ }^{d}$ & 23.4 & 22.7 & NA \\
\hline TOTAL 2 COUNTRIES ${ }^{e}$ & 35.2 & 37.5 & 40.3 \\
\hline
\end{tabular}

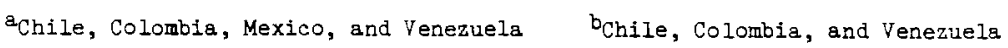

cHong Kong, Malaysia, Singapore, and South Korea

dIndia, Singapore, and South Korea ESingapore and South Korea

Source: Appendix Tables A and D 
ratios are seriously understated. However, it does appear from the comparisons of changes that the U.S. affiliates raised their export propensities more between 1982 and 1986 than the countries did, and especially more than non-affiliates did.

In Asia, on the other hand, the country export propensities are almost all lower than those of U.S. affiliates, despite the overstatement of the country ratios. There was also some sign that the country ratios were coming closer to the affiliate ratios over time.

Another way of examining the role of the U.S. affiliates is through the ir shares in exports of manufactures. Within Latin America, and within the heavily indebted countries as a group, they increased their share substantially over the decade and in each of the periods (Table 6). Their increased share of exports in 1982 to 1986 is not visible in the individual country data for these years, where they appear mostly to have retained their 1982 shares. Thus, the rise in the combined 3 or 4 country ratios implies a shift towards the countries in which the muttinationals played a larger part in export trade.

In the Asian (less indebted) countries, in contrast, U.S. affiliates were losing export shares. The decline was slight outside of Taiwan, and may we lT have been offset by increasing Japanese shares, but there was a substantial decrease in Taiwan and for the less indebted countries, including Taiwan, as a group.

It seems, then, that the strong export performance of U.S, affiliates relative to local firms after 1982 was not a worldwide phenomenon, but was concentrated in the heavily indebted countries. And that export performance of U.S. affiliates consisted more in the degree to which they shifted the direc- 


\section{$-14-$ \\ Table 6}

Exports by U.S. Majority-Owned Manufacturing Affiliates

as Per Cent of Value of Manufactured Exports, Twelve Developing Countries, 1977,1982 , and 1986

\begin{tabular}{|c|c|c|c|}
\hline \multirow[b]{2}{*}{ Heavily Indebted Countries } & 1977 & 1982 & 1986 \\
\hline & & & \\
\hline Brazil & 11.4 & 14.1 & 15.5 \\
\hline Chile & 1.9 & $\mathrm{NA}$ & NA \\
\hline Colombia & 1.9 & 2.6 & 1.4 \\
\hline Mexico & 20.4 & 29.0 & 28.9 \\
\hline Venezuela & 4.9 & NA & 1.6 \\
\hline $\begin{array}{r}\text { Latin America, } 3 \text { Countries }{ }^{a} \\
5 \text { Countries }\end{array}$ & $\begin{array}{l}11.5 \\
10.4\end{array}$ & $\begin{array}{c}15.3 \\
\text { NA }\end{array}$ & $\begin{array}{l}17.7 \\
16.2\end{array}$ \\
\hline Philippines & 17.7 & 18.8 & 18.2 \\
\hline TOTAL 4 COUNTRIES & 12.1 & 15.7 & 17.8 \\
\hline TOTAL 6 COUNTRIES & 11.0 & NA. & 16.3 \\
\hline
\end{tabular}

\section{Other Developing Countries}

$\begin{array}{lccc}\text { Hong Kong } & 8.1 & 6.5 & 4.5 \\ \text { India. } & .3 & \text { NA } & .3 \\ \text { Malaysia } & 9.3 & 18.5 & 19.2-20.6 \\ \text { Singapore } & 18.7 & 14.5 & 18.1 \\ \begin{array}{l}\text { South Korea } \\ \text { Thailand }\end{array} & 1.4 & 1.2 & 1.0 \\ \quad \text { NA } & \text { NA } & 5.7 \\ \quad \text { TOTAL 4 COUNTRIES } & 7.6 & 7.8 & 7.4-7.5 \\ \text { Taiwan } & 6.2 & 4.2 & 3.4 \\ \quad \text { ToTAL 5 COUNTRIES, incl. Taiwan } & 7.2 & 6.8 & 6.0-6.2\end{array}$

$a_{\text {Brazil, Colombia, and Mexico }}$

$\mathrm{b}_{\text {Hong Kong, Melaysie, Singapore, and South Korea }}$

Source: Appendix Tables A and B 
tion of their sales toward exports than in the rate of growth of their exports.

\section{Export Performance by Industry Group}

Since the U.S, affiliates in Latin America are active in a very different set of industries from those in Southeast Asia, their export performance could to some extent reflect the wor $1 \mathrm{dw}$ ide fortunes of their industries rather than the debt circumstances or macroeconomic policies of their host countries (It should be added, however, that the industry distribution of U.S. investment may itself be a reflection of the openness or import substitution orientation of the host countries). The 1982 export distributions of U.S. affiliates were as follows:

\section{Latin America Asia exc. Middle East}

$\begin{array}{lrc}\text { Foods } & 15.0 & 1.1-2.5 \\ \text { Chemicals } & 21.7 & 3.2 \\ \text { Metals } & 7.6 & .9 \\ \text { Non-elect. machinery } & 13.0 & 9.2-10.1 \\ \text { Elect. machinery } & 13.0 & 74.8 \\ \text { Transport equipment } & 14.3 & 3.9 \\ \text { Other manufacturing } & 15.5 & 5.4 \\ & & \end{array}$

For the affiliates in Asian countries, mostly less indebted, three quarters of exports were in electrical machinery, while exports by affiliates in Latin American countries were much more evenly distributed across the seven industry groups.

The growth rates of U.S. affiliate exports in the two areas, by industry, shown in Table 7, point up the fact that foods and metals, which accounted for 23 per cent of exports by Latin American affiliates, but for only 4-6 per cent 
Table 7

Average Annual Growth Rates of Exports by U.S. Majority-Owned Manufacturing Affiliates in Developing Countries, by Region and Industry 1977 to 1982 and 1982 to 1986

\begin{tabular}{|c|c|c|}
\hline Nomine & Val & $\begin{array}{l}\text { Purchasing Power } \\
\text { over U.S. Exports }\end{array}$ \\
\hline $1977-1982$ & $1982-1986$ & $1977-1982 \quad 1982-1986$ \\
\hline
\end{tabular}

\section{All Developing Countries}

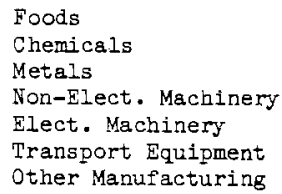

\section{Latin America}

\section{Foods}

Chemicals

Metals

Non-Elect. Machinery

Elect. Machinery

Transport Equipment

Other Manufacturing

\section{Asia, Except Middle East}

$\begin{array}{rrrr}4.2 & 1.0 & -3.9 & -1.0 \\ 22.8 & -4.6 & 13.2 & -6.3 \\ 5.7 & -6.0 & -2.5 & -7.9 \\ 23.6 & 11.8 & 13.9 & 9.7 \\ 16.7 & 6.4 & 7.6 & 4.4 \\ 17.3 & 31.3 & 8.2 & 28.9 \\ 11.6 & 1.9 & 2.8 & 0.0\end{array}$

$\begin{array}{rccc}7.9 & -3.7 & -.6 & -5.4 \\ 28.4 & -10.2 & 18.4 & -12.0 \\ 5.1 & -5.7 & -3.2 & -7.6 \\ 19.5 & 3.1 & 10.3 & 1.2 \\ 12.2 & 14.9 & 3.5 & 12.6 \\ 12.0 & 38.4-40.7 & 3.2 & 35.8-38.1 \\ 18.0 & -6.3-0 & 8.9 & -6.3 \text { to }-1.8\end{array}$

$\begin{array}{lcccc}\text { Foods } & \text { NA } & \text { NA } & \text { NA } & \text { NA } \\ \text { Chemicals } & 6.3 & 19.8-23.8 & -1.9 & 17.6-21.5 \\ \text { Metals } & -5.1 & \text { NA } & -12.6 & \text { NA } \\ \text { Non-Elect. Machinery } & 26.3-28.7 & 18.0-23.4 & 16.4-18.6 & 15.8-21.1 \\ \text { Elect. Machinery } & 17.2-17.5 & 4.9 & 8.0-8.3 & 2.9 \\ \text { Transport Equipment } & \text { NA } & \text { NA } & \text { NA } & \text { NA } \\ \text { Other Manufacturing } & -.6 & \text { NA } & -8.3 & \text { NA }\end{array}$


of Asian affiliates exports in 1982, were slow-growing industries in both periods. Machinery and transport equipment, fast-growing industries, were 40 per cent of Latin American affiliates exports and $88-89$ per cent of exports by Asian affiliates. The sharpest contrast between the two areas was in chemicals, in which export growth accelerated for Asian affiliates, while in Latin America the industry switched from being the fastest growing in exports in 1977-82 to the slowest-growing in 1982-86.

It would appear that the Latin American affiliates would have done considerably better in exporting, on average, if they had been in the same industries as the Asian affiTiates. Within industries, their exports did not seem to grow particularly slowly in 1977-82 relative to Asian or all developing-country affiliates, and even in 1982-86, they grew faster than developing-country affiliates in general in three out of seven industries.

While the growth rates of affiliate exports were not distinctively different between Latin America and Asia or developing countries in general, there was one respect in which there were clear regional differences. Export propensities of affiliates in Latin America were lower than those in Asia or developing countries in general in almost every industry in every period (Table 8). To some extent, that difference may have reflected the fact that Latin American markets were larger than Asian markets, but it may also reflect a difference in policies toward trade: a more inward orientation in Latin America. However, there was a distinct shift toward export orientation by Latin American affiliates in machinery, transport equipment, and "other manufacturing," some beginning in 1977-82, but, in the case of electrical machinery and transport equipment, accelerating in 1982 to 1986 . Affiliates in Asia were also becoming increasingly export-oriented in 1982-86 in every 
Table 8

Export Propensities (Exports as Per Cent of Sales) of

U.S. Majority-Owned Manufacturing Affiliates in Developing Countries, by Region and Industry

1977, 1982, and 1986

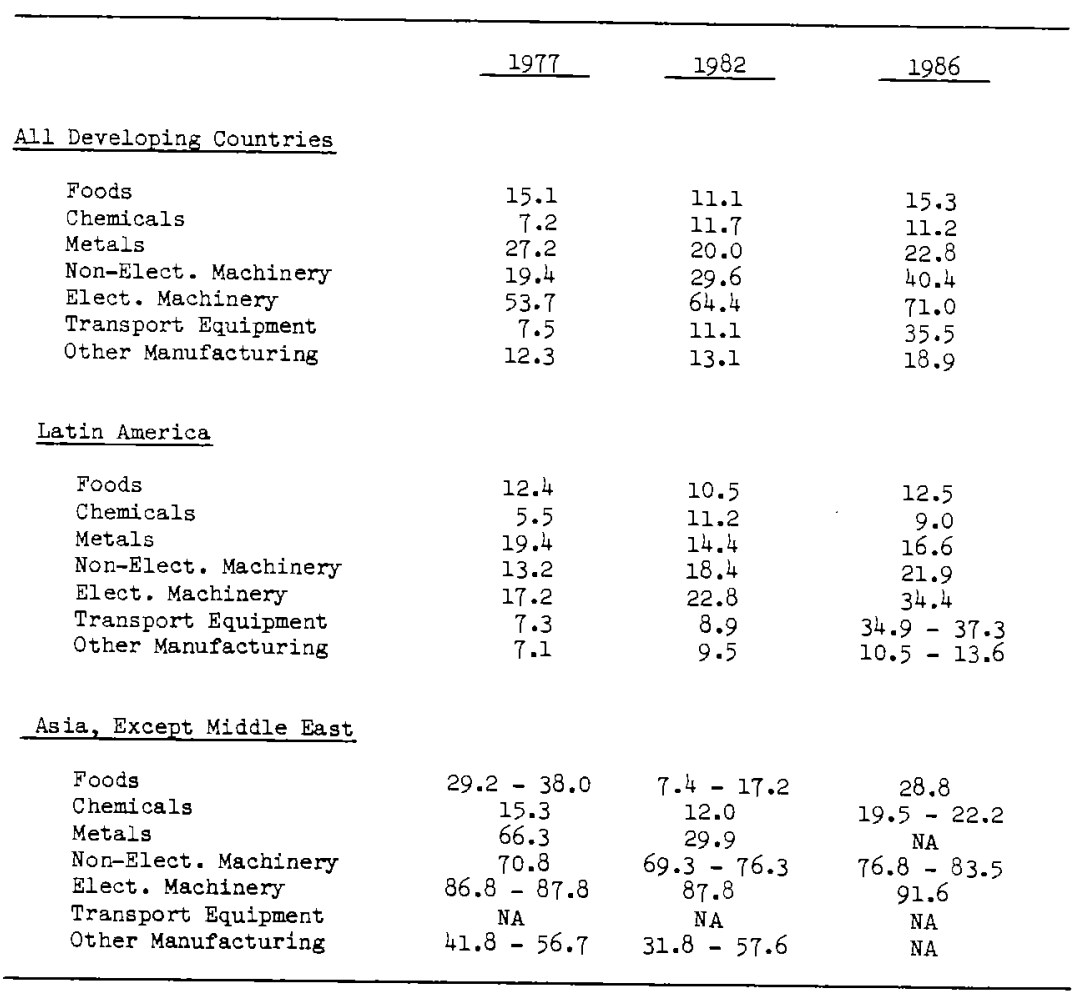

Source: Appendix Tables $E$ and F 
industry for which we can make the calculation, but in some cases they had little room to increase the share of production they sold abroad because it was already so high.

The more inward initial orientation of Latin American affiliates may have given them more scope than Asian affiliates had for switching sales from domestic to foreign markets in 1982-86. However, data for Asian affiliates are too heavily suppressed to permit many comparisons. The largest absolute increase in exports in Latin America, in the transport equipment industry, was accompanied by a similar, but even larger, dectine in domestic sales (Table 9). However, the next largest export increase, in electricai machinery, was accompanied by a much smaller decrease in domestic sales, suggesting that the export growth came out of increased production. In foods, chemicals, metals, and other manufacturing, exports and domestic production both stagnated or, more often, declined, so that we cannot say there was a shift of output from domestic to export markets.

The data are poor for Asian affiliates because there is so much suppression in the source, but there is little indication there of any major shifting. The growth of exports was accompanied either by a growth in domestic sales, or by declines in domestic sales that were too small to provide much export growth.

\section{Conciusions}

The distinctive feature of the export performance of U.S. multinationals' affiliates in heavily indebted countries after the debt crisis began was their sharp shift from selling in host-country markets to exporting. One aspect of this shift was the faster growth of their exports than of the exports of their 
Table 9

Changes in Total Sales, Local Sales, and Exports, U.S. Majority-owned Affiliates in Developing Countries, by Region and Industry, 1982 to 1986

\begin{tabular}{|c|c|c|c|}
\hline & Sales & $\begin{array}{l}\text { Local } \\
\text { Sales }\end{array}$ & Exports \\
\hline \multicolumn{4}{|l|}{ Al1 Developing Countries } \\
\hline $\begin{array}{l}\text { Foods } \\
\text { Chemicals } \\
\text { Metals } \\
\text { Non-Elect. Machinery } \\
\text { Elect. Machinery } \\
\text { Transport Equipment } \\
\text { Other Manufacturing }\end{array}$ & $\begin{array}{r}-1,903 \\
-1,425 \\
-941 \\
586 \\
1,249 \\
-593 \\
-2,225\end{array}$ & $\begin{array}{r}-1,933 \\
-1,210 \\
-810 \\
96 \\
171 \\
-2,376 \\
-2,321\end{array}$ & $\begin{array}{r}30 \\
-215 \\
-131 \\
682 \\
1,420 \\
1,783 \\
96\end{array}$ \\
\hline \multicolumn{4}{|l|}{ Latin America } \\
\hline $\begin{array}{l}\text { Foods } \\
\text { Chemicals } \\
\text { Metals } \\
\text { Non-Elect. Machinery } \\
\text { Elect. Machinery } \\
\text { Transport Equipment } \\
\text { Other Manufacturing }\end{array}$ & $\begin{array}{r}-1,853 \\
-1,770 \\
-783 \\
-170 \\
412 \\
-510 \\
-2,354\end{array}$ & $\begin{array}{c}-1,757 \\
-1,411 \\
-709 \\
-249 \\
-41 \\
-2,299 \text { to }-2,468 \\
-2,184 \text { to }-2,353\end{array}$ & $\begin{array}{c}-96 \\
-359 \\
-74 \\
79 \\
453 \\
1,789-1,958 \\
-1 \text { to }-170\end{array}$ \\
\hline \multicolumn{4}{|l|}{ Asia, Except Middle East } \\
\hline $\begin{array}{l}\text { Foods } \\
\text { Chemicals }\end{array}$ & $\begin{array}{r}-108 \\
425\end{array}$ & $\begin{aligned}-178 \text { to }-263 \\
170-224\end{aligned}$ & $\begin{array}{r}70-155 \\
201-255\end{array}$ \\
\hline $\begin{array}{l}\text { Metals } \\
\text { Non-Elect. Machinery }\end{array}$ & $\begin{array}{l}\text { NA } \\
739\end{array}$ & $\begin{array}{l}\text { NA } \\
65^{-1}-12\end{array}$ & $\begin{array}{c}\text { NA } \\
627-574\end{array}$ \\
\hline $\begin{array}{l}\text { Elect. Machinery } \\
\text { Transport Equipment } \\
\text { Other Manufacturing }\end{array}$ & $\begin{array}{l}808 \\
\text { NA } \\
\text { NA }\end{array}$ & $\begin{array}{l}-127 \\
\text { NA } \\
\text { NA }\end{array}$ & $\begin{array}{r}935 \\
\text { NA } \\
\text { NA }\end{array}$ \\
\hline
\end{tabular}


host-countries. Another was the sharp rise in their export propensities between 1982 and 1986, larger than for the host countries, although the host countries too were shifting their sales to export markets. In both these measures, the behavior of affiliates in the heavity indebted countries differed distinctly from that in the other, less indebted, developing countries, so that it cannot be explained as a general characteristic of the affiliates or of developing countries in general.

Much of the shift in markets by U.S. affiliates involved more a reduction in host country domestic sales rather than increases in exports, and their shares in exports did not rise substantially during this period. The implication is that the affiliates were quicker than domestic firms to reduce the ir local sales, and achieved much of their gains in export propensities that way. It would not be surprising that multinationals reacted this way if debt problems caused host countries to restrict the conversion of local currency income to U.S. dollars, since there would be little incentive for U.S. firms to accumulate depreciating local currencies.

Thus, the flexibility of the multinationals' affiliates, as compared with other firms in their host countries, in the face of the debt crisis was shown by their ability to increase exports from debt-ridden countries rapidly, their ability to change the orientation of these affiliates from domestic sales toward exports, but also by their ability to withdraw from the domestic markets when they became less attractive or more risky.

The results from this study also suggest that multinationals carry a potential to export from production facilities that were largely set up to serve local markets in host countries (i.e. those in Latin America), and that these firms are better equipped to convert import-substituting industries to 
exporting than local firms are. Future research should investigate whether the firms' responses could be explained by changes in their host countries' exchange rates and in trade, balance-of-payments, and investment policies. 


\section{References}

Blomström, Magnus, Irving B. Kravis, and Robert E. Lipsey (1988),

"Multinational Firms and Manufactured Exports from Developing Countries," NBER Working Paper No. 2493, January.

Lipsey, Robert E., Linda Molinari, and Irving B. Kravis (1989), "Measures of Price and Price Competitiveness in International Trade in Manufactured Goods," Paper presented at NBER Conference on Research in Income and Wea 1 th, November $3-4$.

United Nations (1983), Yearbook of Industrial Statistics, 1981.

(1988), Yearbook of Industrial Statistics, 1986.

(1989), Yearbook of Industrial Statistics, 1987.

U.S. Department of Commerce (1981), U.S. Direct Investment Abroad, 1977. Washington, DC, Bureau of Economic Analys is.

(1985), U.S. Direct Investment Abroad: 1982

Benchmark Survey Data, Washington, DC, Bureau of Economic Analysis.

(1988), U.S. Direct Investment Abroad: Operations

of U.S. Parents and their Foreign Affiliates, Revised 1985 Est imates,

Wasthington, DC, Bureau of Economic Analysis, June.

(1989), U.S. Direct Investment Abroad: Operations

of U.S. Parents and their Foreign Affiliates, Revised 1986 Estimates,

Washington, DC, Bureau of Economic Analysis, June. 


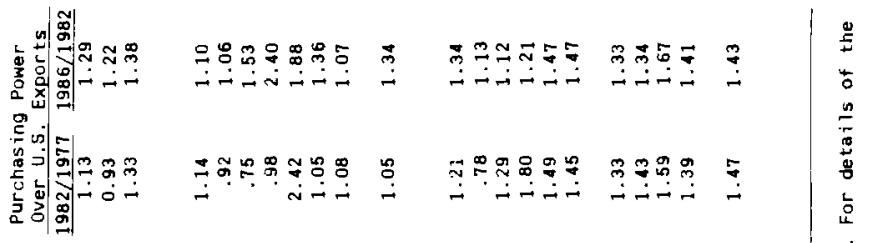
$\stackrel{0}{5}$

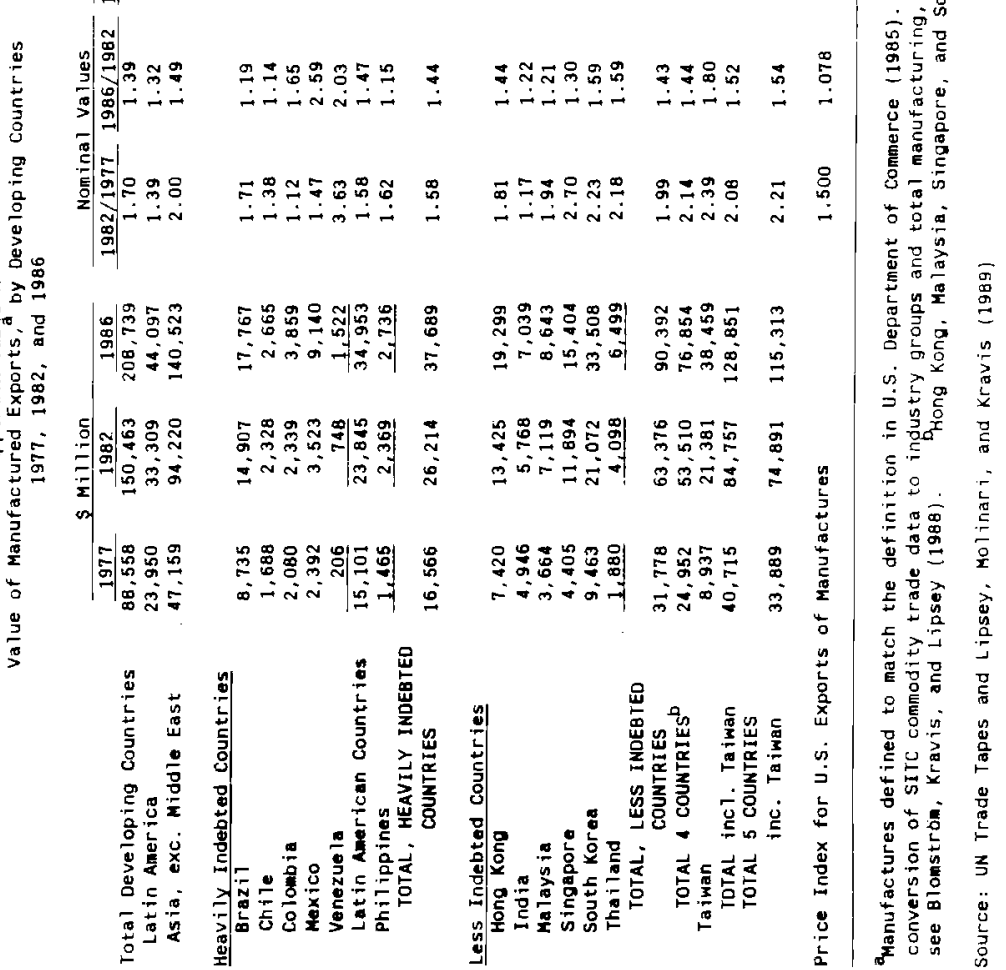




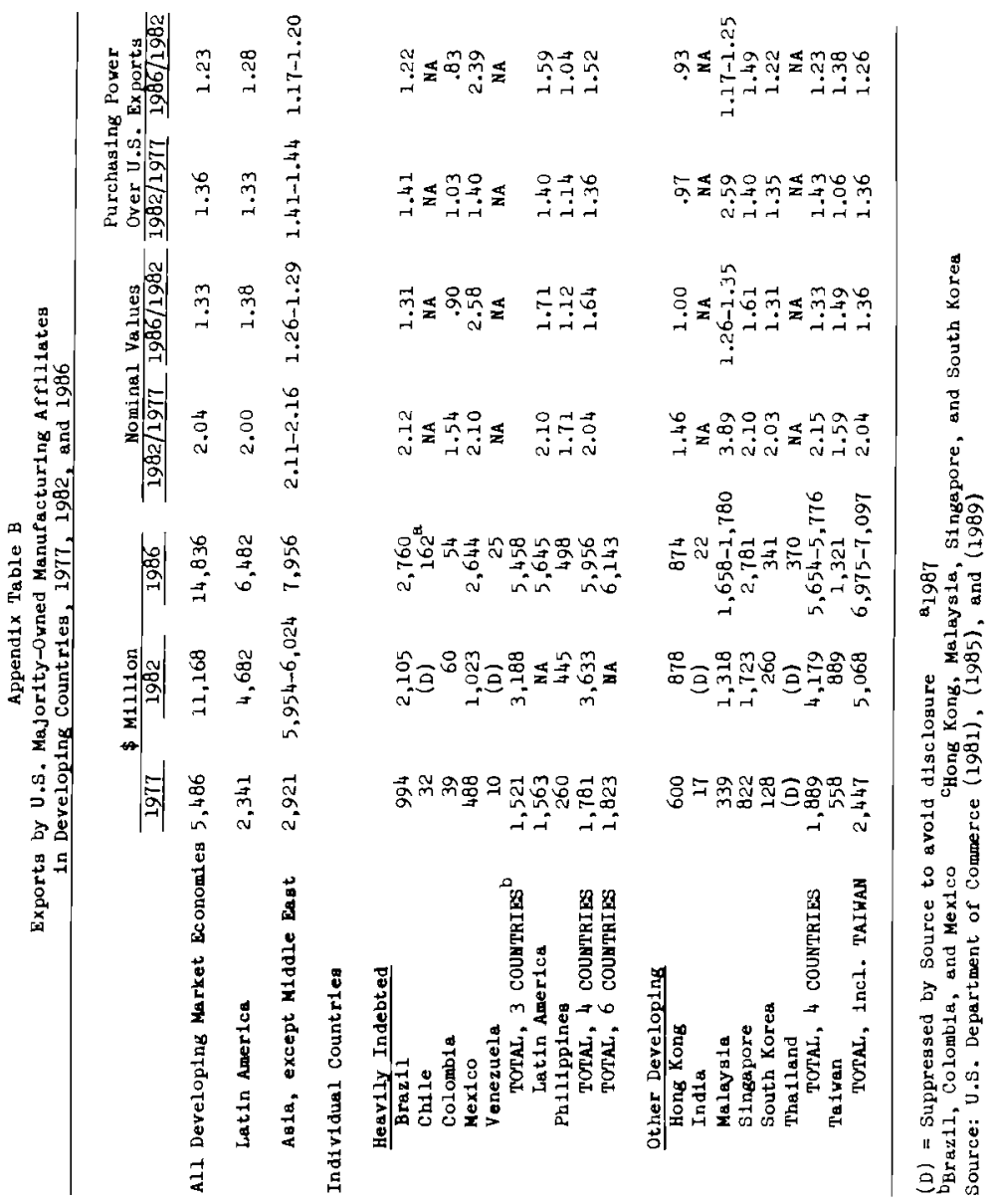


Ail Developing Market Economies

$$
\begin{aligned}
& \text { Latin America } \\
& \text { Asia, except Middle East }
\end{aligned}
$$

Individual Countries

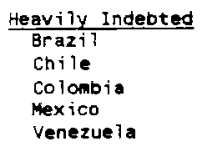

TOTAL, 3 COUNTRIES ${ }^{a}$

TOTAL, 5 COUNTRIES

Philippines

TOTAL, 4 COUNTRIES

TOTAL 5 COUNTRIES

Other Developing Countr ies

\section{Hong Kong}

India

Ma 1 ays ia

Singapore

South Korea

Thei tand

$$
\begin{aligned}
& \text { TOTAL, } 4 \text { COUNTRIES } \\
& \text { TOTAL, } 6 \text { COUNTRIES }
\end{aligned}
$$

\begin{tabular}{|c|c|c|}
\hline 1977 & 1982 & 1986 \\
\hline 30,278 & 50,863 & 45,614 \\
\hline 24,217 & 39,506 & 32,477 \\
\hline 5,125 & 9,933 & 11,912 \\
\hline
\end{tabular}

Taiwan

TOTAL, 5 COUNTRIES, inc 1 . TAIHAN

TOTAL, 7 COUNTRIES, inC1. TAIMAN

11,218

199

992

4,679

2,793

17,037

16, 369

383

1,846

9,438

379

1,316

$4,848 \quad 1,743$

$16,889 \quad 28,321 \quad 25,341$

$19,881 \quad 33,552 \quad 27,463$

$\begin{array}{lll}1,010 & 1,678 & 1,263\end{array}$

$17,899 \quad 29,999 \quad 26,604$

$20,891 \quad 35,230 \quad 28,726$

$\begin{array}{rrr}745 & 1,134 & 1,217 \\ 467 & 508 & 588 \\ 445 & 1,617 & 1,982 \\ 882 & 1,877 & 3,102 \\ 187 & 414 & 588 \\ 234 & 521 & 632 \\ 2,259 & 5,042 & 6,889 \\ 2,960 & 6,071 & 8,109 \\ 787 & 1,497 & 2,075 \\ 3,045 & 6,539 & 8,964 \\ 3,747 & 7,568 & 10,184\end{array}$

abrazil, Colombia, and kexico blong Kong, walaysia, singapore, and south Korea $c_{1987,505}$

Source: U.S. Department of Comerce (1981), (1985), and (1989) 
Appendix Table D

Value of Manufacturing output in Producers' Prices,

Twelve Developing Countries, 1977, 1982, and 1986

\begin{tabular}{|c|c|c|c|}
\hline & \multicolumn{3}{|c|}{ S M Million } \\
\hline & $\overline{1977}$ & 1982 & 1986 \\
\hline \multicolumn{4}{|l|}{ Heavily Indebted Countries } \\
\hline Brazil & NA & NA & NA \\
\hline Chile & 6,684 & 10,947 & 11,120 \\
\hline Colombia & 9,490 & 17,570 & 16,617 \\
\hline Mexico & 48,780 & 82,355 & NA \\
\hline Venezue la & 18,345 & 34,998 & 30,787 \\
\hline Latin America, a Countriesa & 83,299 & 145,870 & NA \\
\hline $\begin{array}{l}\text { Lat in America, } 3 \text { Countriesb } \\
\text { Philippines }\end{array}$ & $\begin{array}{r}34,519 \\
9,897\end{array}$ & $\begin{array}{l}63,515 \\
18,175\end{array}$ & $\begin{array}{l}58,524 \\
12,139\end{array}$ \\
\hline TOTAL, 5 Countries & 93,196 & 164,045 & NA \\
\hline TOTAL, 4 Countries & 44,416 & 81,690 & 70,663 \\
\hline \multicolumn{4}{|l|}{ Other Developing Countries } \\
\hline Hong Kong & NA & 21,836 & 29,224 \\
\hline India & 41,038 & 82,972 & NA \\
\hline Ma Taysia & NA & 16,111 & 16,436 \\
\hline Singapore & 7,486 & 17,272 & 17,170 \\
\hline South Korea & 31,897 & 70,650 & 104,313 \\
\hline Thai land & NA & 27,024 & NA \\
\hline TOTAL, 4 Countries $c$ & NA & 105,911 & 167,143 \\
\hline 3 Countriesd & 80,421 & 170,894 & NA \\
\hline 2 Countriese & 39,383 & 87,922 & 121,483 \\
\hline
\end{tabular}

achile, Colombia, Mexico, and Venezuela

bChile, Colombia, and Venezuela

CHong Kong, Malaysia, Singapore, and South Korea

dIndia, Singapore, and South Korea

esingapore and South Korea

Source: United Nations (1981), (1988), and (1989). 


\section{Appendix Table $E$}

Exports by U.S. Majority-Owned Manufacturing Affiliates in Developing Countries, by Industry Group and Region, 1977, 1982, and 1986

\begin{tabular}{|c|c|c|c|c|c|c|c|}
\hline & \multicolumn{3}{|c|}{ S_Million } & \multicolumn{2}{|c|}{ Nominal Values } & \multicolumn{2}{|c|}{$\begin{array}{l}\text { Purchasing Power } \\
\text { Over U.S. Exports } \\
\end{array}$} \\
\hline & 1977 & 1982 & 1986 & $1982 / 1977$ & $1986 / 1982$ & $1982 / 977 \quad 1$ & $1986 / 1982$ \\
\hline \multicolumn{8}{|c|}{ Al1 Developing Market Economies } \\
\hline Foods & 696 & 857 & 887 & 1.23 & 1.04 & .82 & .96 \\
\hline $\begin{array}{l}\text { Chemicals } \\
\text { Metals }\end{array}$ & $\begin{array}{l}464 \\
453\end{array}$ & $\begin{array}{r}1,296 \\
596\end{array}$ & $\begin{array}{r}1,081 \\
465\end{array}$ & $\begin{array}{l}2.79 \\
1.32\end{array}$ & $\begin{array}{r}.83 \\
.78\end{array}$ & $\begin{array}{r}1.86 \\
.88\end{array}$ & .77 \\
\hline Non-Elect. Mach. & 425 & 1,222 & 1,904 & 2.88 & 1.56 & 1.92 & 1.45 \\
\hline Elect. Mach. & 2,372 & 5,134 & 6,554 & 2.16 & 1.28 & 1.44 & 1.19 \\
\hline Transp. Eq. & 408 & 906 & 2,689 & 2.22 & 2.97 & 1.48 & 2.76 \\
\hline other $\mathrm{Mfg}$. & 669 & 1,159 & 1,255 & 1.73 & 1.08 & 1.15 & 1.00 \\
\hline \multicolumn{8}{|l|}{ Lat in America } \\
\hline Foods & 481 & 702 & 606 & 1.46 & .86 & .97 & .80 \\
\hline Chemicals & 292 & 1,018 & 659 & 3.49 & .65 & 2.33 & .60 \\
\hline Metals & 278 & 355 & 281 & 1.28 & .79 & .85 & .73 \\
\hline Non-Elect. Mach. & 250 & 610 & 689 & 2.44 & 1.13 & 1.63 & 1.05 \\
\hline Elect. Mach. & 342 & 609 & 1,062 & 1.78 & 1.74 & 1.19 & 1.61 \\
\hline Transp. Equip. & 382 & 671 & $2,460-2,629$ & 1.76 & $3.67-3.92$ & 1.17 & $3.40-3.64$ \\
\hline Other Mfg. & 317 & 727 & $557-726$ & 2.29 & $.77-1.00$ & 1.53 & $.77-.93$ \\
\hline \multicolumn{8}{|c|}{ Asia, except Middle East } \\
\hline Foods & 179 & $65-150$ & 220 & NA & NA & NA & NA \\
\hline Chemicals & 139 & 189 & $390-444$ & 1.36 & $2.06-2.35$ & .91 & $1.91-2.18$ \\
\hline Metals & 69 & 53 & NA & .77 & NA & .51 & NA \\
\hline Non-Eiect. Mach. & 172 & $552-607$ & $1,179-1,281$ & $3.21-3.53$ & $1.94-2.32$ & $2.14-2.35$ & $1.80-2.15$ \\
\hline Elect. Mach. & $2,001-2,024$ & 4,478 & 5,413 & $2.21-2.24$ & 1.21 & $1.47-1.49$ & 1.12 \\
\hline Transp. Equip. & $3-26$ & 234 & NA & NA & NA. & NA & NA \\
\hline other Mfg. & 335 & 326 & $\geqslant 261$ & .97 & NA & .65 & NA \\
\hline
\end{tabular}

Notes to Appendix Table E

Sources: U.S. Department of Commerce (1981), Tables III.F5, III.H3, III.H4, and III.H5; (1985), Tables III.D3, III.E3, III.E4, and III.E5; and (1989), Tables 29, 36, 37 , and 38. 


\section{Appendix Table $F$}

Sales by U.S. Majority-Owned Manufacturing Affiliates in Developing Countries, by Industry Group and Region, 1977, 1982, and 1986

\begin{tabular}{|c|c|c|c|}
\hline & 1977 & 1982 & 1986 \\
\hline \multicolumn{4}{|c|}{ Al1 Developing Market Economies } \\
\hline Foods & 4,608 & 7,711 & 5,808 \\
\hline Chemicals & 6,466 & 11,056 & 9,631 \\
\hline Metals & 1,667 & 2,979 & 2,038 \\
\hline Non-Elect. Mach. & 2,191 & 4,131 & 4,717 \\
\hline Elect. Mach. & 4,421 & 7,977 & 9,226 \\
\hline Transp. Equip. & 5,461 & 8,157 & 7,564 \\
\hline other Mfg. & 5,465 & 8,854 & 6,629 \\
\hline \multicolumn{4}{|l|}{ Lat in America } \\
\hline Foods & 3,870 & 6,717 & 4,864 \\
\hline Chemicals & 5,278 & 9,096 & 7,326 \\
\hline Metals & 1,435 & 2,473 & 1,690 \\
\hline Non-Elect. Mach. & 1,899 & 3,315 & 3,145 \\
\hline Elect. Mach. & 1,991 & 2,674 & 3,086 \\
\hline Transp. Equip. & 5,249 & 7,558 & 7,048 \\
\hline other Mfg. & 4,494 & 7,673 & 5,319 \\
\hline \multicolumn{4}{|c|}{ Asia, except Middle East } \\
\hline Foods & $471-612$ & 873 & 765 \\
\hline Chemicals & 911 & 1,578 & 2,003 \\
\hline Metals & 104 & 177 & $78-205$ \\
\hline Non-Elect. Mach. & 243 & 796 & 1,535 \\
\hline Elect. Mach. & 2,306 & 5,099 & 5,907 \\
\hline Transp. Equip. & $\leqslant 212$ & $234-599$ & $242-516$ \\
\hline Other $\mathrm{Mfg}$. & $591-801$ & $566-1,026$ & $261-1,310$ \\
\hline
\end{tabular}

Source: U.S. Department of Commerce (1981), Table III.F5; (1985), Table III.D3 and (1989), Table 29. 
Appendix Table $G$

Value of Manufactured Exports, Individual Developing Countries, by Industry Group and Country, 1977, 1982 and 1986

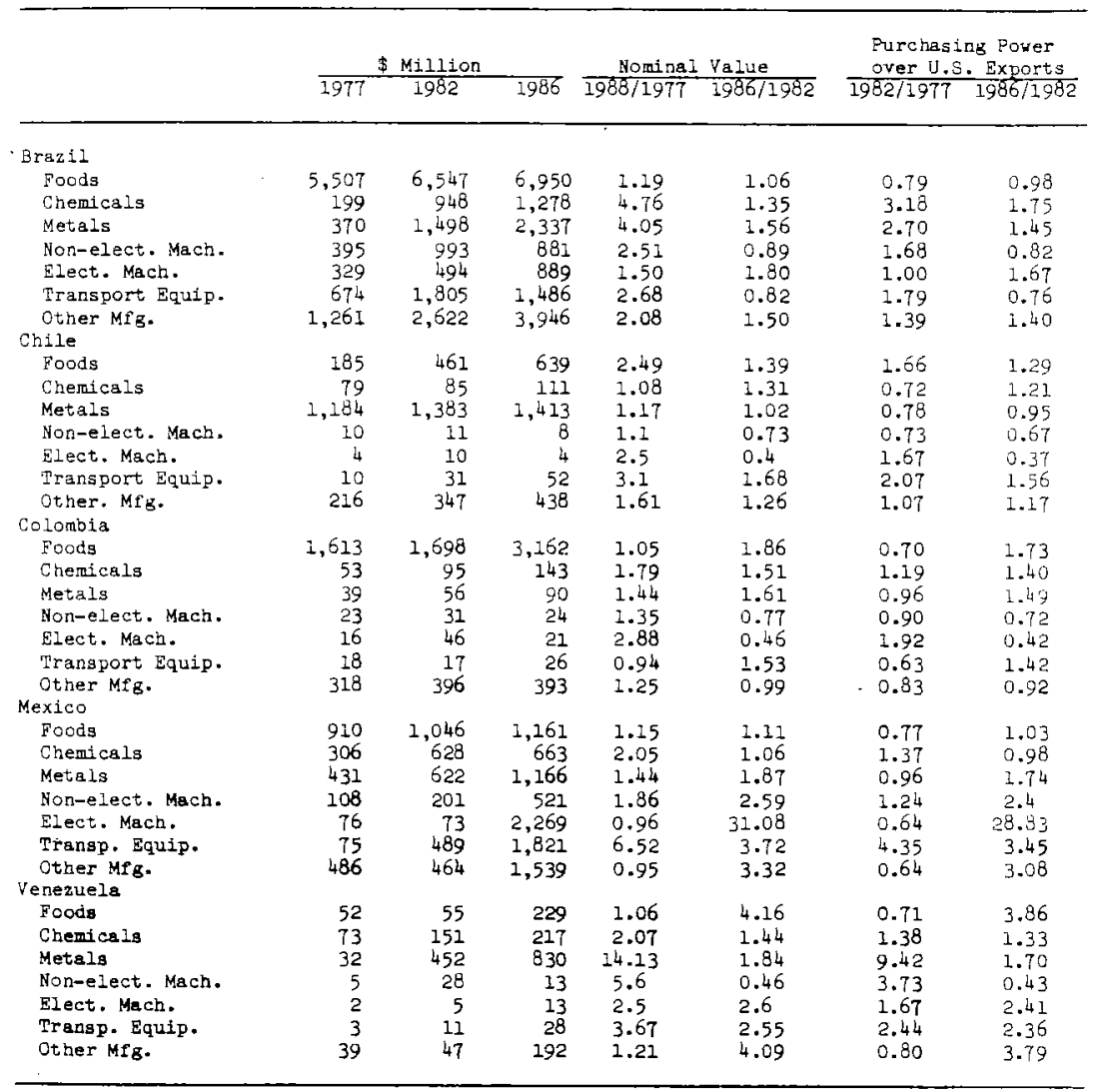


Appendix Table G (continued)

\begin{tabular}{|c|c|c|c|c|c|c|c|}
\hline \multirow{3}{*}{ Philippines } & \multirow{2}{*}{\multicolumn{3}{|c|}{$\frac{\$ \text { Million }}{1977 \text { 1982 }}$}} & \multirow{2}{*}{$\frac{\text { Nominal }}{1988 / 1977}$} & \multirow{2}{*}{$\frac{\text { Value }}{1986 / 1982}$} & \multicolumn{2}{|c|}{$\begin{array}{l}\text { Purchasing Power } \\
\text { Over U.S. Exports }\end{array}$} \\
\hline & & & & & & $1982 / 1977$ & $1986 / 1982$ \\
\hline & & & & & & & \\
\hline Foods & 682 & 920 & 912 & 1.35 & 0.99 & 0.90 & 0.92 \\
\hline Chemicals & 55 & 118 & 261 & 2.15 & 2.21 & 1.43 & 2.05 \\
\hline Metals & 93 & 103 & 244 & 1.11 & 2.37 & $0.7^{4}$ & 2.20 \\
\hline Non-elect. Mach. & 10 & 23 & 16 & 2.3 & 0.7 & 1.53 & 0.65 \\
\hline Elect. Mach. & 29 & 124 & 349 & 4.28 & 2.81 & 2.85 & 2.61 \\
\hline Transport Equip. & 13 & 22 & 32 & 1.69 & 1.45 & 1.13 & 1.35 \\
\hline Dther $\mathrm{Mfg}$. & 583 & 1,059 & 922 & 1.82 & 0.87 & 1.21 & 0.81 \\
\hline Singapore & & & & & & & \\
\hline Foods & 694 & 1,245 & 1,309 & 1.65 & 1.14 & 1.10 & 1.06 \\
\hline Chemicals & 328 & 2,016 & 1,631 & 6.25 & 0.81 & 4.10 & 0.75 \\
\hline Metals & 384 & 1,191 & 743 & 3.10 & 0.62 & 2.07 & 0.58 \\
\hline Non-elect. Mach. & 409 & 1,451 & 3,160 & 3.55 & 2.18 & 2.37 & 2.02 \\
\hline Elect. Mach. & 1,198 & 3,203 & 4.881 & 2.67 & 1.52 & 1.78 & 1.41 \\
\hline Transport Equip. & 295 & 555 & 737 & 1.88 & 1.33 & 1.25 & 1.23 \\
\hline Other. Mfg. & 1,097 & 2,332 & 2,943 & 2.13 & 1.26 & 1.42 & 1.17 \\
\hline Thailand & & & & & & & \\
\hline Foods & 1,010 & 1,920 & 2,480 & 1.90 & 1.29 & 1.27 & 1.20 \\
\hline Chemicals & 23 & 72 & 153 & 3.13 & 2.13 & 2.09 & 1.97 \\
\hline Metals & 272 & 437 & 332 & 1.61 & 0.76 & 1.07 & 0.70 \\
\hline Non-elect. Mach. & 17 & 29 & 182 & 1.71 & 6.28 & 1.14 & 5.82 \\
\hline Elect, Mach, & 65 & 319 & 705 & 4.90 & 2.21 & 3.27 & 2.05 \\
\hline Transport Equip. & 3 & 14 & 25 & 4.67 & 1.75 & 3.11 & 1.56 \\
\hline Other Mfg. & 490 & 1,306 & 2,623 & 2.67 & 2.01 & 1.78 & 1.86 \\
\hline India & & & & & & & \\
\hline Foods & $1,55 ?$ & 1,683 & 1,457 & 1.08 & 0.87 & 0.72 & 0.80 \\
\hline Chemicals & $15 \mathrm{I}$ & 372 & 207 & 2.46 & 0.56 & 1.64 & 0.52 \\
\hline Metals & 641 & 307 & 201 & 0.48 & 0.65 & 0.32 & 0.61 \\
\hline Non-elect. Mach. & 139 & 202 & 200 & 1.45 & 0.99 & 0.97 & 0.92 \\
\hline Elect, Mach. & 91 & 138 & 86 & 1.52 & 0.62 & 1.01 & 0.58 \\
\hline Transp. Equip. & 161 & 258 & 105 & 1.60 & 0.42 & 1.07 & 0.38 \\
\hline Other $\mathrm{Mfg}$. & 2,211 & 2,808 & 4,783 & 1.27 & 1.70 & 0.85 & 1.58 \\
\hline Malaysia & & & & & & & \\
\hline Foods & 1,069 & 1,681 & 1,269 & $1.5 i$ & 0.75 & 1.05 & 0.70 \\
\hline Chemicals & 49 & 173 & 503 & 3.53 & 2.91 & 2.35 & 2.70 \\
\hline Metals & 724 & 718 & 407 & 0.99 & 0.57 & 0.66 & 0.53 \\
\hline Non-elect. Mach. & 39 & 130 & 169 & 3.33 & 1.30 & 2.22 & 1.21 \\
\hline Elect. Mach. & 337 & 1.596 & 2,986 & 4.74 & 1.87 & 3.16 & 1.74 \\
\hline Transp. Equip. & 33 & 123 & 67 & 3.73 & 0.54 & 2.48 & 0.51 \\
\hline Other Mfg. & 1,413 & 2,698 & 3,241 & 1.91 & 1.20 & 1.27 & 1.11 \\
\hline
\end{tabular}


Appendix Table $G$ (concluded)

\begin{tabular}{|c|c|c|c|c|c|c|c|}
\hline & \multicolumn{3}{|c|}{$\$$ Million } & \multicolumn{2}{|c|}{ Nominal value } & \multicolumn{2}{|c|}{$\begin{array}{l}\text { Purchasing Power } \\
\text { over U.S. Exports }\end{array}$} \\
\hline & 1977 & 1982 & 1986 & $1988 / 1977$ & $1986 / 1982$ & $1982 / 1977$ & $1986 / 1982$ \\
\hline \multicolumn{8}{|l|}{ Hong Kong } \\
\hline Foods & 147 & 197 & 236 & 1.34 & 1.20 & 0.89 & 1.11 \\
\hline Chemicals & 65 & 130 & 194 & 2 & 3.49 & 1.33 & 1.38 \\
\hline Metals & 198 & 320 & 436 & 1.62 & 1.36 & 1.08 & 1.26 \\
\hline Non-elect. Mach. & 109 & 518 & 1,167 & 4.75 & 2.25 & 3.17 & 2.09 \\
\hline Elect. Mach. & 1,238 & 2,140 & 3,419 & 1.73 & 1.60 & 1.15 & 1.48 \\
\hline Transport Equip. & & 36 & 36 & 2.12 & 2 & 1.41 & 0.93 \\
\hline Other Mfg. & 5,646 & 10,084 & 13,811 & 1.79 & 1.37 & 1.19 & 1.27 \\
\hline \multicolumn{8}{|l|}{ South Korea } \\
\hline Foods & 893 & 978 & 1,401 & 1.10 & 1.43 & 0.73 & 1.33 \\
\hline Chemicals & 237 & 752 & 1,225 & 3.17 & 1.63 & 2.12 & 1.51 \\
\hline Metals & 1,038 & 3,683 & 3,994 & 3.55 & 1.08 & 2.37 & 1.01 \\
\hline Non-elect. Mach. & 113 & 455 & 1,541 & 4.03 & 3.39 & 2.68 & 3.14 \\
\hline Elect. Mach. & 1,063 & 2,298 & 6,409 & 2.16 & 2.79 & 3.44 & 2.59 \\
\hline Transport Equip. & 632 & 2,962 & 3,739 & 4.69 & 1.26 & 3.12 & 1.17 \\
\hline Other. $\mathrm{Mfg}$. & 5,487 & 9,944 & 15,199 & 1.81 & 1.53 & $1.2 I$ & 1.42 \\
\hline
\end{tabular}

Source: United Nationg World Trade Tapes and Appendix Table A 
Appendix Table H

Exports of Manufactures by Firms Other Than U.S. Multinationals' Affiliates, Developing Countries, 2977,1982 , and 1986

\begin{tabular}{|c|c|c|c|c|c|c|c|}
\hline & \multicolumn{3}{|c|}{ S Million } & \multicolumn{2}{|c|}{ Nominal Values } & \multicolumn{2}{|c|}{$\begin{array}{l}\text { Purchasing Power } \\
\text { over U.S. Exports }\end{array}$} \\
\hline & 1977 & 1982 & $19 \overline{986}$ & $1982 / 1977$ & $1 9 8 6 \longdiv { 1 9 8 2 }$ & $1982 / 1977$ & $1986 / 1982$ \\
\hline \multicolumn{8}{|l|}{ A11 Developing } \\
\hline Market Economies & 83,072 & 139,295 & 193,805 & 1.68 & 1.39 & 1.12 & 1.29 \\
\hline Latin America & 21,609 & 28,627 & 37,506 & 1.32 & 1.31 & 0.88 & 1.22 \\
\hline \multicolumn{8}{|l|}{ Asia, except } \\
\hline Middle East & 44,238 & 88,065 & 132,567 & 1.99 & 1.51 & 1.33 & 1.40 \\
\hline \multicolumn{8}{|l|}{$\begin{array}{l}\text { Individual Countries } \\
\text { Heavily Indebted Co }\end{array}$} \\
\hline Brazil & 7,741 & 12,802 & 15,007 & 1.65 & 1.17 & 1.10 & 1.09 \\
\hline Chile & 1,656 & NA & NA & $\mathrm{NA}$ & NA & NA & NA \\
\hline Colombia & 2,041 & 2,279 & 3,805 & 1.12 & 2.67 & .75 & 1.55 \\
\hline Mexico & 1,904 & 2,500 & 6,496 & 1.22 & 2.60 & .81 & 2.41 \\
\hline Venezue la & 196 & NA & 2,497 & NA & NA & NA & NA \\
\hline 3 Latin Am. & & & & & & & \\
\hline Countriesa & 11,686 & 17,581 & 25,308 & 1.50 & 1.44 & 1.00 & 1.34 \\
\hline $\begin{array}{l}\text { Phil ippines } \\
4 \text { HEAVILY }\end{array}$ & 1,205 & 1,924 & 2,238 & 1.60 & 1.16 & 1.07 & 1.08 \\
\hline IND. COUNT. & 12,891 & 19,505 & 27,546 & 1.54 & 1.41 & 1.03 & 1.31 \\
\hline \multicolumn{8}{|c|}{ Less Indebted Countries } \\
\hline Hong Kong & 6,820 & 12,547 & 18,425 & 1.84 & 1.47 & 1.23 & 1.36 \\
\hline India & 4,929 & NA & 7.017 & NA & NA & NA & NA \\
\hline Malaysia & 3,325 & 5,801 & $6,863-6,985$ & $1.7 \mathrm{~A}$ & $1.18-1.20$ & 1.16 & $1.09-1.11$ \\
\hline Singapore & 3,583 & 10,171 & 12,623 & 2.84 & 1.24 & 1.89 & 1.15 \\
\hline South Korea & 9,335 & 20,812 & $33, \pm 67$ & 2.23 & 1.59 & 1.49 & 1.47 \\
\hline \multirow{3}{*}{$\begin{array}{l}\text { Tha iland } \\
4 \text { Less Ind. } \\
\text { Count. }\end{array}$} & NA & NA & 6,129 & NA & NA & NA & NA \\
\hline & & & & & & & \\
\hline & 23,063 & 49,331 & $71,078-71,200$ & 2.14 & 1.44 & 1.43 & $1 \cdot 34$ \\
\hline \multirow{4}{*}{$\begin{array}{l}\text { Taiwan } \\
5 \text { LESS IND. } \\
\text { COUNT., INC } \\
\text { TAIWAN }\end{array}$} & 8,379 & 20,492 & 37,138 & 2.45 & 1.81 & 1.63 & 1.68 \\
\hline & & & & & & & \\
\hline & & & & & & & \\
\hline & 31,442 & 69,823 & $108,216-108,338$ & 2.22 & 1.55 & 1.48 & 1.44 \\
\hline
\end{tabular}

aBrazit, Colombia, and Mexico

bong Kong, Malaysia, Singapore, and South Korea 